\title{
Detection and cellular localization of Xanthomonas campestris pv. viticola in seeds of commercial 'Red Globe' grapes
}

\author{
Guilherme de Oliveira Tostes ${ }^{1}$, João Sebastião de Paula Araujo ${ }^{1}$, Antônio Roberto Gomes Farias ${ }^{1}$, Daniela \\ Ângela Rossinol Frade² \& Fábio Lopes Olivares²
}

'Departamento de Fitotecnia, Instituto de Agronomia, Universidade Federal Rural do Rio de Janeiro, BR 465, km 7, 23851970, Seropédica, RJ, Brazil; ${ }^{2}$ Laboratório de Biologia Celular e Tecidual, Centro de Biociências e Biotecnologia, Universidade Estadual do Norte Fluminense Darcy Ribeiro, Av. Alberto Lamego 2000, 28013-600, Campos dos Goytacazes, RJ, Brazil

Author for correspondence: João Sebastião de Paula Araújo, e-mail: araujoft@ufrrj.br

\begin{abstract}
Commercial grapevine fruit (Vitis vinifera) of the Red Globe variety were collected in vineyards from Vale do São Francisco lower basin, an area of occurrence of grapevine bacterial canker. Seeds were extracted, classified as symptomatic or asymptomatic and processed in order to be observed under light (LM) and scanning electron microscopy (SEM) along with silver-enhanced immunogold labeling, to allow bacterial detection using a policlonal antibody against Xanthomonas campestris pv. viticola (Xcvi), etiological agent of the disease. The seed samples showed bacterial aggregates associated to the tegument surface and to the first parenchymal layer beneath the seed tegument. Bacterial identity was confirmed by immunogold labeling. This appears to be the first report of Xcvi associated to asymptomatic seeds and berries, suggesting a systemic mechanism to spread and colonize different tissues and sites, driving attention to seeds, presenting them as an important niche for survival and dissemination of this pathogen. These results point towards the need of including seed-bearing fruit in studies regarding Xcvi epidemiology.
\end{abstract}

Key words: Vitis vinifera, grapevine bacterial canker, immunogold labeling, scanning electron microscopy.

\section{INTRODUCTION}

Xanthomonas campestris pv. viticola (Nayudu) Dye $(X c v i)$ is the causal agent of bacterial canker of grapevine (Vitis vinifera L.). Presently, it is the main grapevine bacteriosis in the Vale do São Francisco lower basin (northeast of Brazil), and is classified as a quarantine pest. Since its introduction in the northeastern region more than a decade ago (Malavolta et al., 1998; Lima et al., 1999), $X c v i$ has caused serious damage to grapevines. Primary order symptoms such as necrotic lesions on leaves are commonly observed in areas where the disease occurs. There is a prevalence of cankers deriving from vascular tissue obstruction in the branches, tendrils and stalks which stops sap flow and impairs the vegetative and reproductive growth of grapevine. Secondary symptoms such as wilting and drying of branches are also observed (Araujo \& Robbs, 2000 ) or, yet, an abnormal development of clusters and berries that can depreciate or even make fruit commercially unviable.

Severity or symptoms varies according to the cultivar. Among the different materials planted in the region, the variety Red Globe is the most vulnerable to the disease (MAPA, 2012), mainly during the rainy season, when higher humidity associated with high temperatures allows an exponential increase of pathogen populations, increasing fruit losses.
Studies on $\mathrm{Xcvi}$ interaction with its natural host were performed by Araujo et al. (2004) with symptomatic and asymptomatic materials, using scanning electron microscopy among other techniques. The authors concluded that bacterial cells adhere to the plant surface by means of non-polar fixing on mono-layers, and that the most frequent adhesion sites are the surface of veins and trichomes on leaf blades. After reaching a favorable site, Xcvi can resist removal, which is a selective advantage responsible for increasing and stabilizing the resident population (Araujo, 2001; Nascimento \& Mariano, 2004).

Araujo et al. (2005) developed antibodies against $X c v i$. These allowed the authors to specifically detect $X c v i$ cells associated to the surface and the interior of symptomatic and asymptomatic plant tissues in grapevines. Based on structural interaction studies and on specific immunolocalization, the authors showed the pathogen's capacity to cause local and systemic infection in the vegetative and reproductive axis.

The systemic colonization nature of some species of the genus Xanthomonas is associated to different plant hosts, although Ryan et al. (2011) reported that some species from the group, such as Xanthomonas citri pv. citri, usually cause local infection and colonization. Therefore, studying each individual pathosystem is important.

Studies by Araujo et al. (2004) advanced the understanding of the grapevine-Xvci pathosystem. However, 
not all plant organs were analyzed. The current study was performed to investigate whether commercial fruit seeds of variety Red Globe could be a potential bacterial colonization and settlement niche, using light and scanning electron microscopy associated with immunolocalization techniques.

\section{MATERIAL AND METHODS}

In situ incursions were performed in the irrigated perimeter of Senador Nilo Coelho, micro-region of Vale do São Francisco River in the state of Pernambuco, Brazil. Vineyards planted with the Red Globe variety and presenting a background of vine bacterial canker were evaluated. Asymptomatic grape clusters were collected in the area. The seeds were extracted from the berries, classified as symptomatic or asymptomatic (Figure 1) and parts of such material (measuring approximately $0.5 \mathrm{~cm}^{2}$ ) were used for light microscopy. The material used for scanning electron microscopy was vertically and longitudinally transected in the median portion. Parts of 20 seeds (ten symptomatic and ten asymptomatic) were immediately transferred to a fixing solution containing $2.5 \%$ glutaraldehyde and $4 \%$ paraformaldehyde in potassium phosphate buffer $(50 \mathrm{mM}$, $\mathrm{pH}$ 6.8). After 24 hours at room temperature, the segments were washed three times for $15 \mathrm{~min}$ in the same buffer.
Additional steps were performed following the protocol of James et al. (1994).

\section{Light microscopy}

Samples were dehydrated in a increasing ethanol series $(15,30,50,60,70,80,90,100 \%$ ethanol in water $\mathrm{v} / \mathrm{v}$ ), and were kept in each solution for $15 \mathrm{~min}$. Next, they were filtered with a LR White medium grade crylic resin (London Resin Company) for seven days and kept in the refrigerator. The blocks were prepared with individual samples placed in transparent gelatin capsules containing resin and were polymerized in a stove $\left(60^{\circ} \mathrm{C}\right)$ for 18 hours. The polymerized capsules were selected and observed using the ultra-microtome loupe and were lapidated using a steel blade, allowing the obtainment of trapezoid shaped blocks. Semi-thin sections $(0.7-1 \mu \mathrm{m})$ were obtained from such blocks using a Reichert-Jung Ultracut E ultra-microtome. The sections were collected in glass slides heated on metallic plates. Toluidine blue staining $(0.1 \%)$ was performed and a new slide heating was done. Samples were examined with a Zeiss Axioplan light microscope.

\section{Scanning electron microscopy}

The samples were post-fixed in an aqueous solution of osmium tetroxide $(1 \%)$, washed three times in phosphate buffer and dehydrated in an increasing acetone series (30,
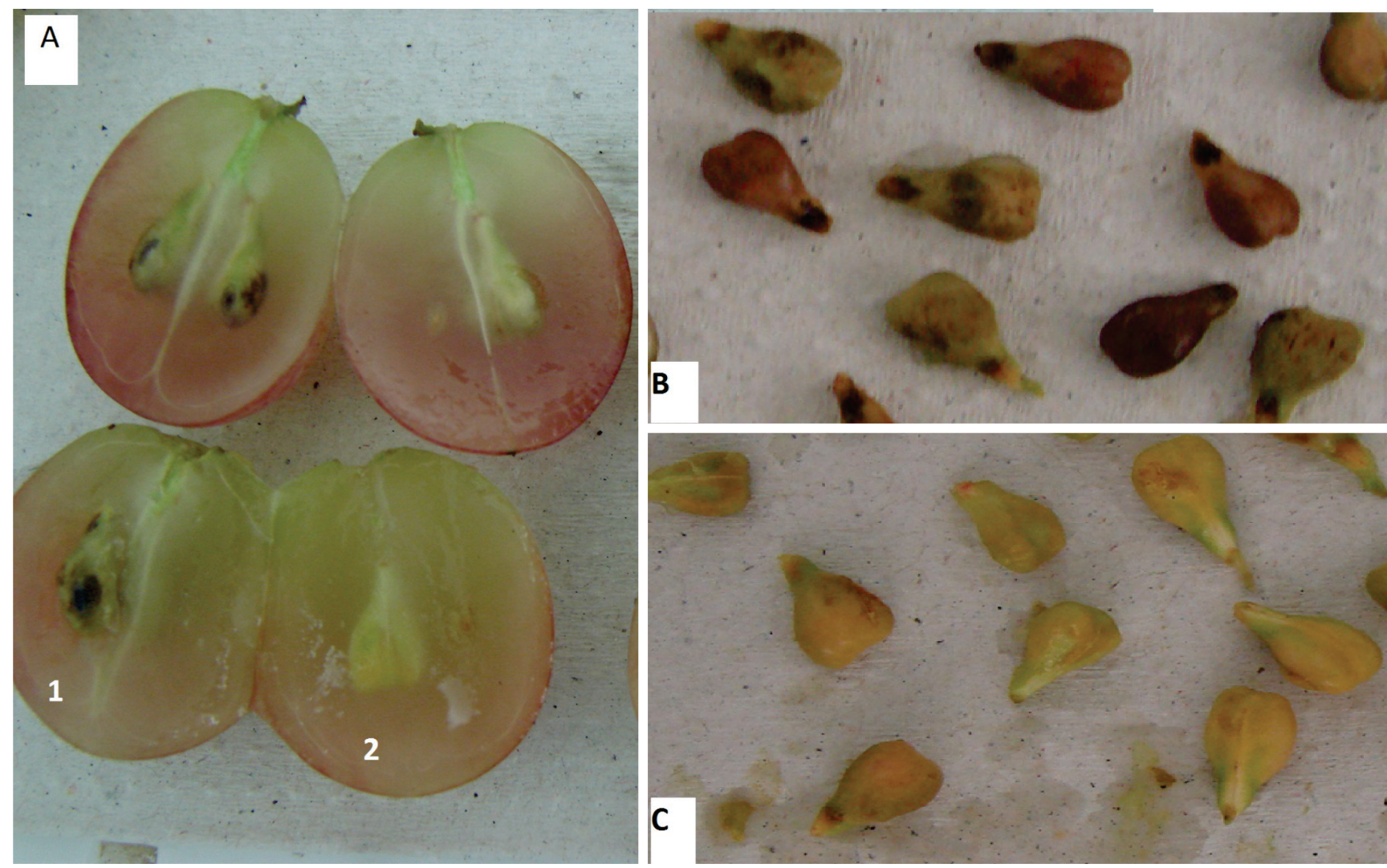

FIGURE 1 - Berries and seeds of the Red Globe variety. A. Asymptomatic berries with symptomatic (1) and asymptomatic seeds (2); B. Seeds with typical symptoms on the tegument; C. Absence of canker symptoms. 
50, 70, 90, 100\% acetone). After that, selected samples were transferred to a critical point drier (Mod. CPD 030, Bal-tec), where they were completely dried by replacing the acetone with liquid carbonic gas kept under high pressure. Later on, the liquid $\mathrm{CO}_{2}$ turned into gassy $\mathrm{CO}_{2}$ by applying a temperature of $36^{\circ} \mathrm{C}$ and pressure of 70 atm $\left(\mathrm{CO}_{2}\right.$ critical drying point). After this procedure the samples were covered with a silver film to increase electronic conductivity, applying an $18 \mathrm{~mA}$ electronic current and gold deposition time of $240 \mathrm{sec}$ with an automatic sputter coater (Mod. SCD 050, Bal-tec), providing a $300 \mathrm{~nm}$ thick coverage. Samples were examined on a Zeiss DSEM 962 scanning electron microscope.

\section{Immune-staining with colloidal gold followed by silver enhancement}

Semi-thin tissue sections $(0.9 \mu \mathrm{m})$ were placed in a drop of water over a microscope slide, covered with $1 \%$ gelatin solution in water and fixed at $40^{\circ} \mathrm{C}$, followed by incubation in blocking solution ( $3 \%$ bovine serum albumin, $0.2 \%$ Tween 20 in phosphate buffered saline) for 1 hour at room temperature. Then, after a fast freshwater washing procedure, the primary AC4558 antiserum was applied (Araujo et al., 2005) at a 1:400 dilution. The material was incubated in a moist chamber for 1 hour at $25^{\circ} \mathrm{C}$. Sections were then washed in $0.5 \%$ bovine serum albumine, $0.1 \%$ Tween 20 in PBS and then in sterilized distilled water (5 min each), and dried with a paper towel. Next, $50 \mu 1$ of the secondary antibody were applied along with $5 \mathrm{~nm}$ diameter gold particles, diluted in a 1:100 IGL solution for 4 hours at $25^{\circ} \mathrm{C}$ in a moist chamber. After this period, the slides were washed for $5 \mathrm{~min}$ in $0.5 \%$ bovine serum albumine, $0.1 \%$ Tween 20 in PBS and in sterilized distilled water again (5 min each) and dried. To allow the visualization on the light microscope, immunogold labeling was silver enhanced using the Intense SE BL Silver Enhancement set (Janssen Life Sciences Products) as described by Vanderbosh et al. (1986). The reaction was visualized by the deposition of an opaque blackish/brownish precipitate around the gold particles linked to the secondary antibody and corresponding to $X c v i$ epitopes, the specific detection target.

\section{RESULTS AND DISCUSSION}

Berries collected in vineyards planted with 'Red Globe' where grapevine bacterial canker had already been detected presented symptomatic and asymptomatic seeds (Figure 1). In all ten symptomatic seeds it was possible to confirm the presence of $\mathrm{Xcvi}$, whereas eight from the ten asymptomatic seeds samples were also infected.

The observation of symptomatic seeds under the SEM (Figure 2A, B) confirmed the presence of bacterial aggregates adhered to the tegument surface. Tissue disarray became evident in such regions. This is a characteristic of canker symptomalogy following Xcvi colonization (Figure $2 \mathrm{C}, \mathrm{D})$. Observations at $3000 \times$ and $5000 \times$ magnification indicated the preence of 1.9-2.3 $\mu \mathrm{m}$ long and 0.6-0.8 $\mu \mathrm{m}$ wide bacilliform cells (Figure 2E, F), a typical morphological characteristic of the genus Xanthomonas as described by Swings et al. (1993) and Araujo et al. (2004). This was evidence of bacterial colonization and also confirmed the identity of Xcvi using immune-staining techniques.

By examining the electron micrographs of asymptomatic seeds (Figure 3A), it was possible to observe $X c v i$ cells in the cavity close to the connection regions between the seeds and the petiole, where the conductor bundles that individually feed the seeds are set (Figure $3 \mathrm{~B})$. The captured image, exactly in this region - which is a connection point - suggests that it is the initial colonization and settling site in the seeds (Figure 3C, D), since they are seeds with absence of symptoms and thus showing low Xcvi population density (Figure $3 \mathrm{E}, \mathrm{F}$ ) when compared to symptomatic tissues (Figure 2E, F) with intense colonization. Such observation corroborates the hypotheses of Araujo et al. (2004) regarding Xcvi systemic colonization. Thus, the presence of $X c v i$ in the plant conductive elements that link and feed the whole plant turns such elements into an infection path to the fruit and seeds.

Based on light microscopy analysis of transversal and longitudinal sections stained with toluidine blue, it was possible to distinguish different tissue systems in the anatomy of the grape seed var. Red Globe (Figure 2A). Moreover, by using such a technique, it was possible to localize the bacteria inside the seed tissue, colonizing the inner space between the endosperm and the tegument. In the colonization sites there is a possible deposition of plant gels indicated by the coloring metachromasy behavior in high density negative charge, characterized by a purple color (Figure 3B).

Finally, confirmation of the etiological agent for grapevine bacterial canker associated to asymptomatic fruit seeds was possible by analysing the images obtained after colloidal gold immune-staining, followed by silver enhancement (Figure 4C-F). Thus, it was possible to prove, based on the specificity of the AC4558 antiserum, the identities of the observed bacteria under the light microscope, with the formation of black precipitates in the $X c v i$ infection and colonization sites (Figures 4D, E). These results are in conformity with the reports by Araujo et al. (2005) and Tostes (2012). A detail of the methodological sequence to identify the bacterium is schematized in Figure 4C, based on studies by James et al. (1994) and Olivares et al. (1997), reporting immune-stained diazothrophic endophytic bacteria associated with wheat and sugar cane crops. First, the AC4558 antiserum is linked to the epitopes found on $X c v i$ cellular walls. Next, the secondary antibody linked to gold particles is connected to the primary one. The black precipitate on the images represents the deposition of silver ions around the colloidal gold, allowing signal detection at light microscope resolution and, consequently, allowing the observation of Xcvi-colonized spots (Figure 4D, E). The reaction's specificity can be verified by comparing the 


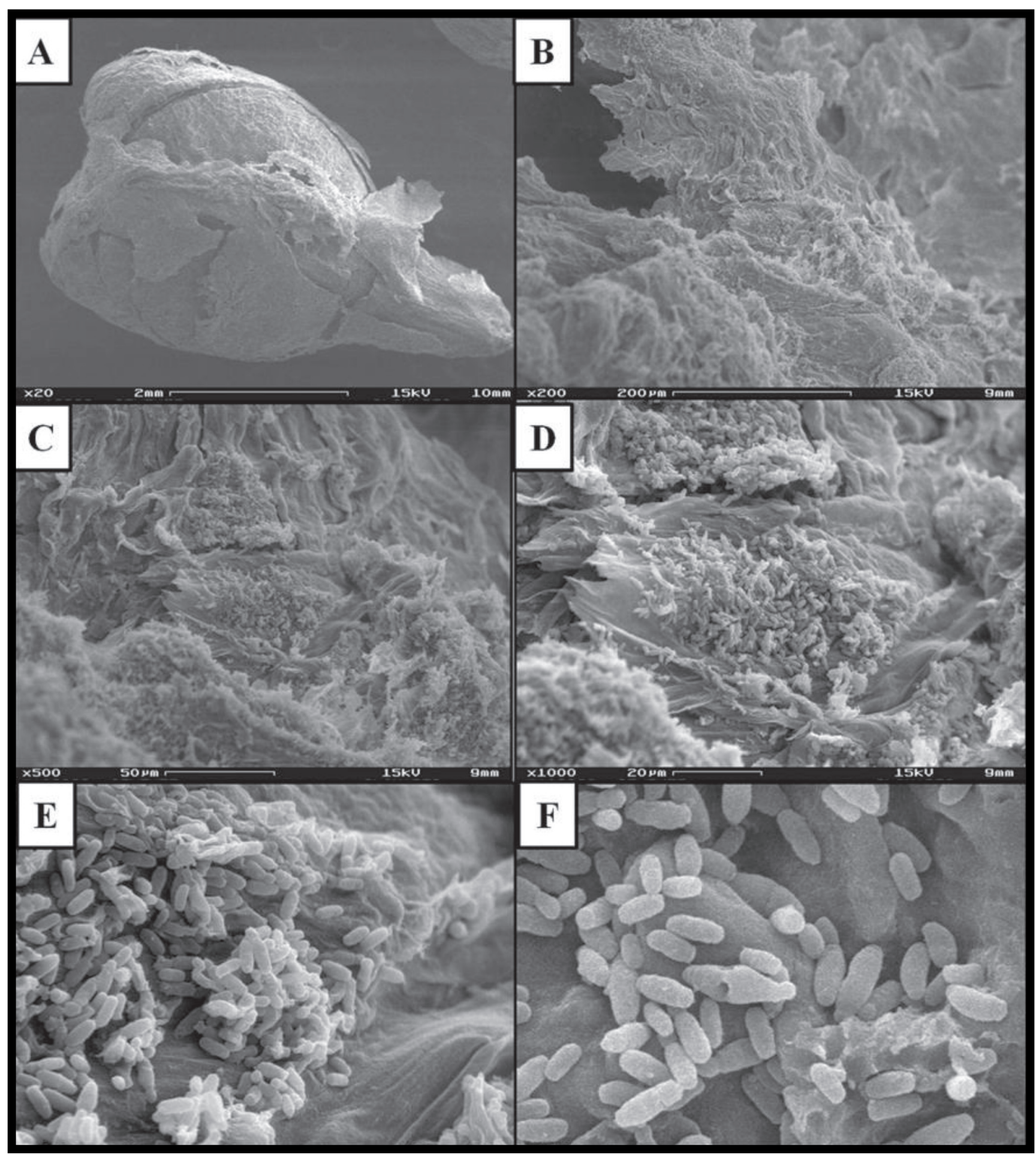

FIGURE 2 - Scanning electron microscopy from grape seeds of the Red Globe variety. A. Canker symptoms and epithelial tissue detachment; B. Cellular and tissue integrity impairment; C, D. Mass of bacterial cells colonizing large areas of injured tissue; E, F. Mass formed by bacilliform cells.

observed staining patterns in Figure 4E and the negative control (pre-immune serum replacing the anti-Xcvi primary antibody; Figure 3F).

Despite considerable progress in detecting $X c v i$ in asymptomatic samples (Araujo et al., 2005; Freitas, 2012), there remain several questions that should guide future research. The ecology of this bacterium is poorly understood and little is known about epiphytic growth, mechanisms of pathogenesis, modes of dissemination and survival.

$\mathrm{Xcvi}$ in infected tissues of grapevine is known as an important primary inoculum source. In this way, Silva et al. (2102) observed that Xcvi survives in grapevine-infected 


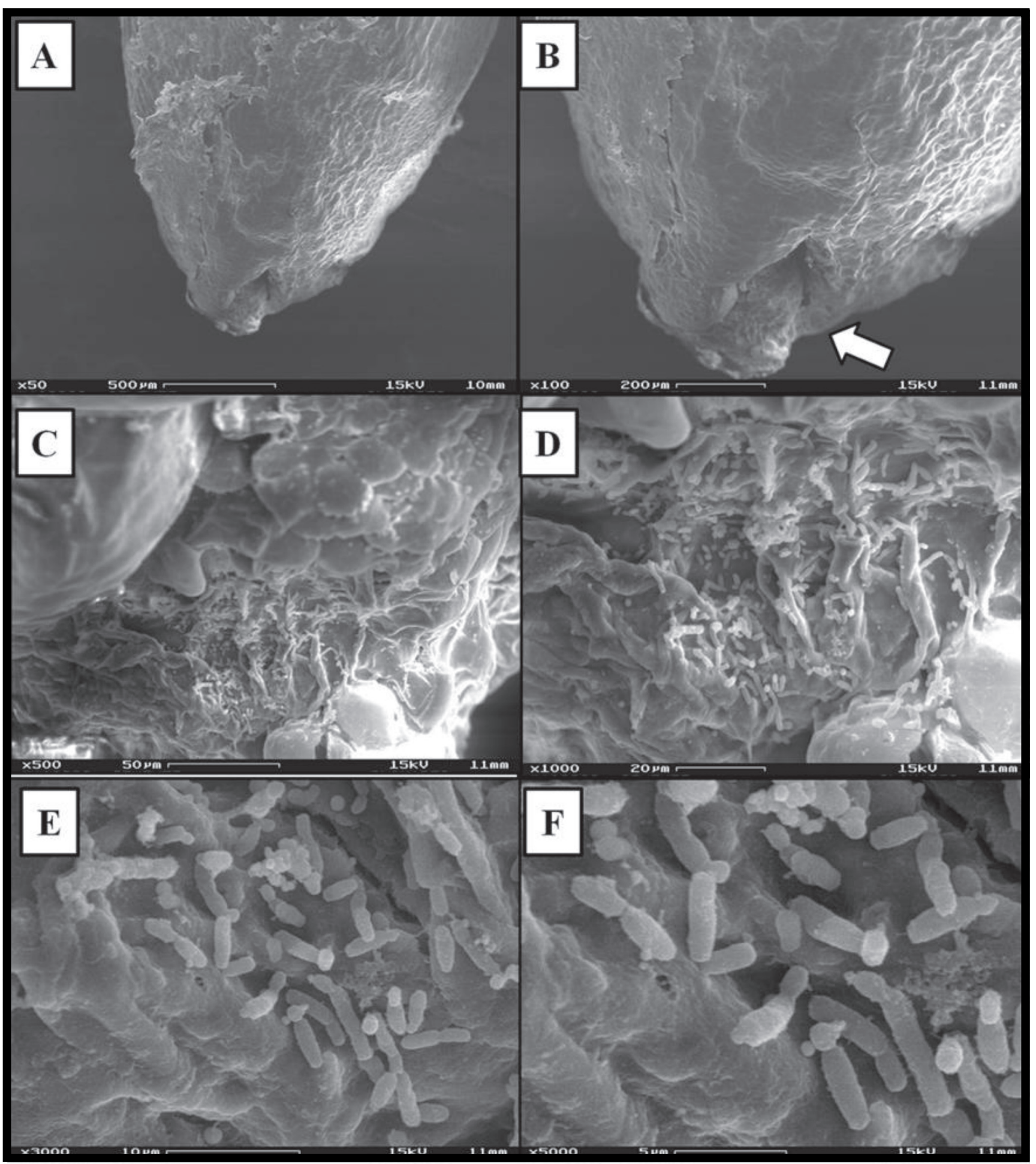

FIGURE 3 - Scanning electron microscopy of asymptomatic grape seeds of the Red Globe variety. A. Absence of canker symptoms; B. Detailed view of the vascular bundle insertion point; C, D. Link of the vascular bundle colonized by Xcvi; E, F. Xcvi cells adhered to the tegument surface and supposedly promoting the beginning of the seed internal cavity colonization.

tissues on soil surface for at least 80 days, but is eradicated by composting in 10 days.

Bacterial diseases associated with seeds remain a problem, causing significant economic losses and being responsible for the re-emergence of disease by the introduction into new areas (Gitaitis \& Walcott, 2007). According to Darrasse et al. (2010), seeds are passive carriers of a diverse microbial flora that can affect the physiology of seedlings and can favors disease spread. Although grapevine is not commercially propagated by 


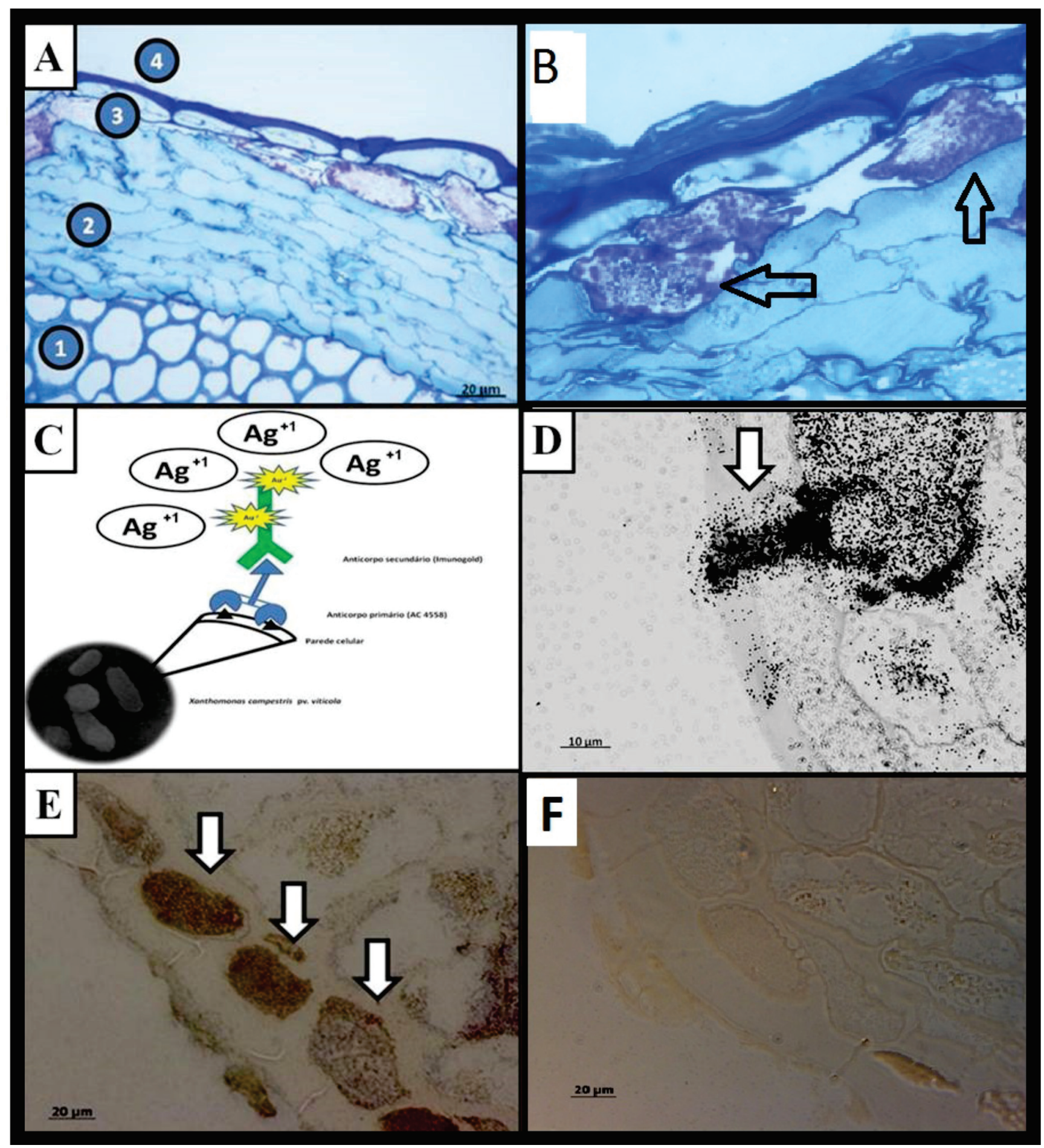

FIGURE 4 - A. Bright field optical microscopy of seed transversal sections of asymptomatic grapes of the Red Globe variety stained with $0.1 \%$ toluidine blue. It is possible to notice the tissue organization and integrity, showing the following anatomic organization sequence: 1, parenchyma; 2, endosperm; 3 , internal space between the endosperm and the tegument; 4 , tegument; B. Detailed view of the toluidine blue metachromasy pattern in the presence of bacterial aggregates (arrows) found beneath the tegument layer (notice the purple color); $\mathbf{C}$. Schematics showing the immune-staining biochemical reaction; D. Bright field optical microscopy of a non-stained longitudinal section, where it is possible to observe the efficiency of the immune-staining reaction with the formation of black precipitate around the Xcvi cellular mass. The arrow indicates Xcvi cells leaving the tegument's internal area towards the external area through a cavity; E. Positive immune-staining reaction and a detailed view of the $X c v i$ allocation spot in the seed's internal tissue; F. Negative control of the immunestaining assay detailing the absence of black precipitate formation in the place where the Xcvi is located. 
seed, the majority of commercial cultivars have seeds, which makes possible the spread of Xcvi from one region to another along with the berries marketed. Thus, our research emphasizes the importance of seeds as source of inoculum.

Structural analysis of symptomatic and asymptomatic grape seeds from areas affected by grapevine bacterial canker demonstrated the presence of bacteria associated to the tegument surface and/or to the tissue's interior. The presence of $\mathrm{Xcvi}$ in symptomatic and asymptomatic seeds, confirmed by immunological techniques, represents the first evidence of $X c v i$ presence in seeds from berries in asymptomatic clusters. Considering that grapevines are not usually evaluated regarding seed phytosanitary status, such colonization niche could be important for the dissemination and survival of Xcvi.

\section{ACKNOWLEDGEMENTS}

This work was supported by a grant from Conselho Nacional de Desenvolvimento Científico e Tecnológico CNPq/MAPA and Coordenação de Aperfeiçoamento de Pessoal de Nível Superior - CAPES.

\section{REFERENCES}

Araujo JSP, Bueno JRF, Cruz GB, Oliveira BC, Robbs CF, Ribeiro RLD, Polidoro JC (2005) Produção e caracterização de anticorpos policlonais contra Xanthomonas campestris pv. viticola. Pesquisa Agropecuária Brasileira 40:305-309.

Araujo JSP, Oliveira BC, Olivares FL, Reis-Junior FB, Cruz GB, Robbs CF, Ribeiro RLD (2004) Imunomarcação de Xanthomonas campestres pv. viticola com ouro utilizando anticorpos policlonais. Agronomia 38:29-33.

Araujo JSP (2001) Perfil epidemiológico e subsídios para o controle de Xanthomonas campestris pv. viticola (Nayudu) Dye, agente do cancro bacteriano da videira (Vitis vinifera L.) no Brasil. PhD Thesis, Universidade Federal Rural do Rio de Janeiro. Seropédica, RJ, Brazil.

Araujo JSP, Robbs CF (2000) Sintomatologia, patogenicidade e controle do cancro bacteriano da videira (Xanthomonas campestris pv. viticola) no Brasil. Agronomia 34:83-86.

Darrasse A, Darsonval A, Boureau T, Brisset M, Durand K, Jacques M (2010) Transmission of plant-pathogenic bacteria by nonhost seeds without induction of an associated defense reaction at emergence. Applied and Environmental Microbiology 76:67876796.
Freitas AC (2012) Detecção molecular de Xanthomonas campestris pv. viticola em videiras assintomáticas. MSc Thesis, Universidade Federal de Brasília. Brasília, DF, Brazil.

Gitaitis RD, WalcottRR (2007) The epidemiology and management of seedborne bacterial diseases. Annual Review of Phytopathology 45:371-397.

James EK, Reis VM, Olivares FL, Baldani JI, Döbereiner J (1994) Infection of sugar cane by the nitrogen-fixing bacterium Acetobacter diazotrophicus. Journal of Experimental Botany 45:757-766.

Lima MF, Ferreira MASV, Moreira WA, Dianese JC (1999) Bacterial canker of grapevine in Brazil caused by Xanthomonas campestris pv. viticola. Fitopatologia Brasileira 24:440-443.

MAPA(2012) Sistema de Agrotóxicos Fitossanitários (AGROFIT). Sistema Federal de Legislação Agrícola Federal - Sislegis. Available at: http://extranet.agricultura.gov.br/sislegis. Accessed on October 20, 2012.

Malavolta-Junior VA, Almeida IMG, Sugimori MH, Ribeiro IA, Rodrigues-Neto J, Pires EJP, Nogueira EMC (1998) Ocorrência de Xanthomonas campestris pv. viticola em videira no Brasil. Fitopatologia Brasileira 23(Suppl.):211.

Nascimento ARP, Mariano RLR (2004) Cancro bacteriano da videira: Etiologia, epidemiologia e medidas de controle. Ciência Rural 34:301-307.

Olivares FL, James EK, Baldani JI, Döbereiner J (1997) Infection of mottled stripe disease-suscetible and resistant sugar cane varietaies by the endothytic diazotroph Herbaspirillum. New Phytologist 135:723-737.

Ryan RP, Vorhölter F, Potnis N, Jones JB, Sluys MAV, Bogdanove AJ, Dow JM (2011) Pathogenomics of Xanthomonas: Understanding bacterium-plant interactions. Nature Reviews Microbiology 9:344-355.

Silva AMF, Menezes EF, Souza EB, Melo NF, Mariano RLR (2012) Sobrevivência de Xanthomonas campestris pv. viticola em tecido infectado de videira. Revista Brasileira de Fruticultura $34: 757-765$

Swings J, Vauterin L, Kersters K (1993) The bacterium Xanthomonas. In: Swings JG, Civerolo EL (Eds). Xanthomonas. London, UK. Chapman \& Hall. pp. 121-156.

Tostes GO (2012) Nichos de sobrevivência de Xanthomonas campestris pv. viticola em tecidos de bagas e sementes de videira. MSc Thesis, Universidade Federal Rural do Rio de Janeiro. Seropédica, RJ, Brazil.

Vanderbosh KA (1986) Light and electron microscopic visualization of uricase by immunogold labelling of sections of resin-embedded soybean. Journal of Microscopy 143:187-197. 